\title{
Crisphead Lettuce Cultivar Response to Fertilizer Phosphorus
}

\author{
R.T. Nagata, C.A. Sanchez, and F.J. Coale \\ Everglades Research and Education Center, Institute of Food and Agricultural Sciences, University \\ of Florida, P. 0. Box 8003, Belle Glade, FL 33430 \\ Additional index words. Histosol, Lactuca sativa, soil test
}

\begin{abstract}
Four field experiments were conducted during 1988 to 1990 to evaluate the response to fertilizer $P$ of six crisphead lettuce (Latuca sativa $\mathbf{L}$.) cultivars grown on Histosols. There were season $\times$ cultivar interactions for total mass produced, marketable yield, and $P$ uptake by lettuce. A significant yield response to fertilizer $P$ was demonstrated during all four seasons. The performance of individual cultivars within a given season led to cultivar $\times P$ rate interactions for marketable yield. However, there were no significant $P$ rate $\times$ cultivar interactions for total mass produced, $P$ uptake, and marketable yield during the one season when growing conditions were near ideal. Calculated critical soil-test $\mathbf{P}$ values for both eastern and western lettuce types produced in Florida were all within error currently associated with $P$ fertilizer recommendations for lettuce produced in Florida. Therefore, we conclude that no immediate change in $\mathbf{P}$ fertilizer recommendations is required for the new western-type lettuce cultivars produced on Histosols in Florida.
\end{abstract}

The production of high-quality crisphead lettuce depends to a great extent on soil fertility. Under most conditions, lettuce shows a pronounced yield and quality response to fertilizer $\mathrm{P}$ (Alt, 1987; Greenwood et al., 1980; Sanchez et al., 1988). In southern Florida, $\mathrm{P}$ fertilizer recommendations for lettuce grown on Histosols (organic soils) are based on a water-extractable $\mathrm{P}$ test (Sanchez, 1990), with a given recommendation at each soiltest value when the fertilizer is applied broadcast and $-60 \%$ less P when the fertilizer is to be banded (Sanchez et al., 1990). However, these $\mathrm{P}$ recommendations for crisphead lettuce do not consider the cultivar or type grown.

In the United States, crisphead lettuce is generally grouped into eastern or western foliar types. Eastern type cultivars are generally adapted to the Histosols and climate of the eastern United States, while western-type cultivars are generally adapted to the mineral soils and climate of the western United States. The eastern lettuce type is represented by 'Ithaca', 'Green Lake', 'Minetto', 'South Bay', 'Raleigh', and others. Their leaves are pale green with savoyed ruffled edges and have small basal stem diameters. The heads are protected from the sun by large wrapper leaves that whorl above the head. The western lettuce types, represented by 'Vanguard' and 'Salinas', have thick, smooth, slightly undulated, dark-green leaves (Thompson and Ryder, 1961). The heads of western-type lettuce cultivars are generally larger than eastern types and have a large basal stem diameter. In many areas, there is a market preference for the western types of lettuce. Hence, two recently released cultivars in Florida ('Florical 48060' and 'Florical 50011') have western phenotypic characteristics but are adapted for the organic soils and climate of Florida (Guzman et al., 1990). Little information is available regarding cultivar response of lettuce to fertilizer $P$, and we have no information to indicate if these two lettuce types respond differently to $\mathrm{P}$ fertilizer. The objective of these studies was to evaluate the yield responses to $\mathrm{P}$ of six lettuce cultivars commercially produced in the United States.

Received for publication 1 Aug. 1991. Accepted for publication 20 Apr. 1992. University of Florida Expt. Sta. Journal Series no. R-02158. The cost of publishing this paper was defrayed in part by the payment of page charges. Under postal regulations, this paper therefore must be hereby marked advertisement solely to indicate this fact.

'Current address: Yuma Agricultural Center, Univ. of Arizona, 6425 W. 8th Street, Yuma, AZ 85364.

\section{Materials and Methods}

Four field experiments were conducted during 1988 to 1990 to evaluate the response of six crisphead lettuce cultivars to fertilizer P. Weather conditions during each experiment and selected soil properties at each site are shown in Table 1. Experiments Fall 1988, Winter 1989, Winter 1990, and Spring 1990 were planted 22 Oct. 1988, 27 Jan. 1989, 10 Nov. 1989, and 28 Feb. 1990, respectively. Each cultivar was harvested at optimum maturity, defined as that point when heads would be harvested commercially. All experiments were conducted on a Pahokee muck (euic, hyperthermic Lithic Medisaprist). The P rates selected were based on preplant soil test levels with the intent of generating a meaningful response curve for each experiment. Phosphorus rates were $0,25,50,100$, and $200 \mathrm{~kg} \mathrm{P} /$ ha in Fall 1988 and 0, 50, 100, 200, and $400 \mathrm{~kg}$ P/ha for Winter 1989, Winter 1990, and Spring 1990. Triple superphosphate was the $\mathrm{P}$ source in all experiments. The experiments were splitplot designs with five replications. Phosphorus treatments were the main plots and were arranged in a randomized completeblock design with lettuce cultivars as the subplots. The main plots measured 7.3 (eight $0.9-\mathrm{m}$ beds) $\times 15.2 \mathrm{~m}$. The subplots were individual rows of six lettuce cultivars ('South Bay', 'Raleigh', 'Salinas', 'Ithaca', 'Florical 48060', and 'Florical 50011') randomized in the center six beds of the main plot. A guard row of 'South Bay' was planted on each border within the main plot. 'South Bay' and 'Raleigh' are eastern-type lettuce cultivars commonly produced on Florida Histosols (Guzman and Gull, 1984). 'Ithaca' is an eastern-type cultivar developed for the mineral soils of New York and New Jersey but grown on Histosols and previously in Florida. 'Salinas' is a western-type cultivar commonly produced in the western United States. 'Florical 48060' and 'Florical 50011' are cultivars having western phenotypic characteristics and adapted to Florida conditions.

In all experiments, $\mathrm{Zn}, \mathrm{Mn}$, and B were applied at 9, 9, and $2 \mathrm{~kg} \cdot \mathrm{ha}^{-1}$, respectively. For each experiment, K was applied based on a preplant soil test (Sanchez, 1990). Phosphorus, K, and micronutrients were applied as a preplant broadcast and disked into the soil before planting. Nitrogen was applied at 50 $\mathrm{kg} \mathrm{N} / \mathrm{ha}$ as a sidedress at the six-leaf stage. Water was supplied using subsurface irrigation from field ditches by maintaining a water table $-60 \mathrm{~cm}$ below the soil surface (Snyder et al., 1978).

Lettuce was seeded in elevated double-row beds on $0.9-\mathrm{m}$ centers and thinned at the four-leaf stage to a $25 \mathrm{~cm}$ intrarow 
Table 1. Weather conditions and soil properties for four field experiments conducted with crisphead lettuce during 1988 through 1990.

\begin{tabular}{|c|c|c|c|c|c|c|c|c|c|}
\hline \multirow[b]{3}{*}{ Expt. } & \multicolumn{4}{|c|}{ Air temp $2 \mathrm{~m}$ above ground level $\left({ }^{\circ} \mathrm{C}\right)$} & \multirow{3}{*}{$\begin{array}{c}\text { Solar } \\
\text { radiation } \\
\left(\mathrm{W} \cdot \mathrm{m}^{-2}\right)\end{array}$} & \multirow{3}{*}{$\begin{array}{c}\text { Rainfall } \\
(\mathrm{mm})\end{array}$} & \multirow{3}{*}{$\begin{array}{c}\text { Pan } \\
\text { evaporation } \\
(\mathrm{mm})\end{array}$} & \multirow{3}{*}{$\begin{array}{l}\text { Soil } \\
\mathrm{pH}\end{array}$} & \multirow{3}{*}{$\begin{array}{c}\text { Soil } \\
\text { test } \mathrm{P} \\
\left(\mathrm{mg} \cdot \mathrm{dm}^{-3}\right)\end{array}$} \\
\hline & \multicolumn{2}{|c|}{ Night } & \multicolumn{2}{|c|}{ Day } & & & & & \\
\hline & Mean & Range & Mean & Range & & & & & \\
\hline Fall 1988 & 13.9 & $-1.1-22.8$ & 27.4 & $16.1-31.7$ & 117.7 & 56 & 241 & 6.1 & 11.5 \\
\hline Winter 1989 & 13.0 & $-1.7-20.6$ & 27.2 & $12.2-32.2$ & 151.6 & 63 & 311 & 6.6 & 4.0 \\
\hline Winter 1990 & 11.8 & $-4.4-20.5$ & 25.6 & $5.6-31.1$ & 122.2 & 136 & 258 & 6.9 & 6.0 \\
\hline Spring 1990 & 14.1 & $3.9-19.5$ & 28.1 & $21.1-32.3$ & 199.0 & 82 & 340 & 6.9 & 3.8 \\
\hline
\end{tabular}

spacing to give an approximate population of 60,000 plants/ha. Heads were harvested from $6 \mathrm{~m}$ of each of two rows per bed, and marketable yields were determined after grading according to standard marketing criteria (U.S. Dept. of Agriculture, 1973).

Two lettuce plants were collected from each plot at maturity for mineral analysis. Plant material was dried at 60C for $48 \mathrm{~h}$. After wet ashing (Wolf, 1982), $\mathrm{N}$ and $\mathrm{P}$ were determined colorimetrically, and $\mathrm{K}, \mathrm{Ca}, \mathrm{Mg}, \mathrm{Zn}, \mathrm{Fe}, \mathrm{Mn}$, and $\mathrm{Cu}$ by atomic absorption spectrometry. Soil samples were taken before planting and 30 days after fertilizer application. The samples collected 30 days after fertilization were taken at random from within the lettuce bed to a depth of $15 \mathrm{~cm}$. These samples were analyzed for water-soluble P according to Sanchez (1990). Because of weather conditions, we were not able to take soil samples after fertilization in Spring 1991. Data were subjected to analysis of variance using SAS GLM (SAS, 1982).

\section{Results and Discussion}

Weather conditions varied markedly among the four seasons during which these experiments were conducted (Table 1), and this variability in growing conditions is clearly reflected in lettuce response. The pooled analysis of variance for the four seasons shows highly significant $(P<0.01)$ season $\times$ cultivar interactions for total mass produced, marketable yield, and $\mathrm{P}$ uptake by lettuce (Table 2). The cultivar $\times \mathrm{P}$ rate and season $\times$ cultivar $\times P$ rate interactions were also significant for marketable yield but not for total mass produced or for $\mathrm{P}$ uptake by lettuce. An analysis of variance for individual seasons shows significant differences in marketable yields due to $\mathrm{P}$ rate and cultivar during all seasons (Table 3 ). This result was expected, since we selected sites that were low in soil P (Sanchez and Burdine, 1988).

During Fall 1988, growing conditions were nearly ideal, and lettuce achieved nearly the maximum yield attainable under Florida conditions. During this season, the cultivar $\times \mathrm{P}$ rate interaction was not statistically significant, indicating that under these conditions all cultivars showed a similar response to fertilizer P. During this season, yields averaged 49.1, 54.1, 56.3, 57.7, and $59.1 \mathrm{Mg} \cdot \mathrm{ha}^{-1}$ at $0,25,50,100$, and $200 \mathrm{~kg} \mathrm{P} / \mathrm{ha}$, respectively. Total P uptake for Fall 1988 averaged 20.6, 24.4, 29.9, 32.7, and $30.2 \mathrm{~kg} \cdot \mathrm{ha}^{-1}$ at $0,25,50,100$, and $200 \mathrm{~kg} \mathrm{P} / \mathrm{ha}$, respec tively.

The cultivar $\times \mathrm{P}$ interaction for marketable yield was statistically significant during Winter 1989, Winter 1990, and Spring 1990. However, the lack of significant cultivar $\times P$ rate interactions with respect to total mass produced and $\mathrm{P}$ uptake and a close inspection of the individual responses during each season suggest that these $\mathrm{P}$ rate $\times$ cultivar interactions for marketable yield were largely driven by the performance of individual cultivars within a given season (Table 4).

In Winter 1989, lettuce was grown on a site that had a dense subsurface horizon (hard pan) which limited the effectiveness of subsurface irrigation. This site only received 63 $\mathrm{mm}$ of rainfall (Table 1) and soil moisture stress was a limiting factor. All cultivars showed a linear response to $\mathrm{P}$ during this season. The relative degree to which each cultivar responded to $\mathrm{P}$ during this particular site-season probably was greatly influenced by the ability of each cultivar to tolerate the drought conditions.

In Winter 1990, the lettuce was subjected to a freeze on 24 and 25 Dec. During this season, 'Salinas' and 'Ithaca' produced

Table 2. Pooled analysis of variance for four seasons of $\mathrm{P}$ and cultivar effects on total lettuce mass produced, marketable yield, and $\mathrm{P}$ uptake by lettuce.

\begin{tabular}{|c|c|c|c|c|c|c|c|}
\hline \multirow[b]{3}{*}{ Source } & \multirow[b]{3}{*}{ df } & \multicolumn{6}{|c|}{ Response } \\
\hline & & \multicolumn{2}{|c|}{ Total mass } & \multicolumn{2}{|c|}{ Marketable yield } & \multicolumn{2}{|c|}{$P$ uptake } \\
\hline & & MS & $P>\mathrm{F}$ & MS & $P>\mathrm{F}$ & MS & $P>\mathrm{F}$ \\
\hline Replication (R) & 4 & 405.10 & 0.0012 & 939.83 & 0.0001 & 116.67 & 0.0408 \\
\hline Season (S) & 3 & $13,506.8$ & 0.0001 & $40,948.27$ & 0.0001 & $4,832.22$ & 0.0001 \\
\hline Error $A(S \times R)$ & 12 & 166.5 & 0.1002 & 263.50 & 0.0001 & 107.74 & 0.0102 \\
\hline $\mathrm{P}$ rate $(\mathrm{P})$ & 1 & $18,692.49$ & 0.0001 & $15,422.43$ & 0.0001 & $9,226.17$ & 0.0001 \\
\hline$P \times S$ & 3 & $1,086.30$ & 0.0001 & $1,885.84$ & 0.0018 & 101.61 & 0.0828 \\
\hline Error $B(P \times S \times R)$ & 16 & 82.68 & 0.0033 & 238.39 & 0.0001 & 33.99 & 0.7616 \\
\hline Cultivar (C) & 5 & 225.56 & 0.0041 & $1,455.50$ & 0.0001 & 139.09 & 0.0112 \\
\hline $\mathrm{C} \times \mathrm{S}$ & 15 & 558.55 & 0.0001 & $1,061.61$ & 0.0001 & 124.95 & 0.0006 \\
\hline $\mathrm{C} \times \mathrm{P}$ & 5 & 66.69 & 0.1049 & 429.1 & 0.0001 & 3.0 & 0.9971 \\
\hline$C \times S \times P$ & 15 & 22.27 & 0.8661 & 137.0 & 0.0118 & 36.68 & 0.6891 \\
\hline Error C & 519 & 36.3 & - & 67.3 & --- & 46.42 & -.. \\
\hline
\end{tabular}

${ }^{2}$ Analysis of variance conducted as split-split plot, where season is main plot, $\mathrm{P}$ rate (continuous variable) is subplot, and cultivar is sub-sub-plot. 
Table 3. Analysis of variance for $\mathrm{P}$ and cultivar effects on marketable lettuce yield by season. ${ }^{\mathrm{z}}$

\begin{tabular}{|c|c|c|c|c|c|c|c|c|c|}
\hline \multirow[b]{3}{*}{ Source } & \multirow[b]{3}{*}{ df } & \multicolumn{8}{|c|}{ Season } \\
\hline & & \multicolumn{2}{|c|}{ Fall 1988} & \multicolumn{2}{|c|}{ Winter 1989} & \multicolumn{2}{|c|}{ Winter 1990} & \multicolumn{2}{|c|}{ Spring 1990} \\
\hline & & MS & $P>\mathrm{F}$ & MS & $P>\mathrm{F}$ & MS & $P>\mathrm{F}$ & MS & $P>\mathrm{F}$ \\
\hline Replication (R) & 4 & 95.37 & 0.0728 & 11.31 & 0.8930 & 78.45 & 0.0631 & $1,195.67$ & 0.0956 \\
\hline$P$ rate $(P)$ & 1 & $1,260.07$ & 0.0126 & $10,522.45$ & 0.0077 & 226.49 & 0.0231 & $9,076.21$ & 0.0104 \\
\hline Error $A(P \times R)$ & 4 & 67.90 & 0.1876 & 428.93 & 0.0001 & 17.57 & 0.7261 & 438.37 & 0.0238 \\
\hline Cultivar (C) & 5 & 376.88 & 0.0001 & 30.98 & 0.5832 & $2,332.41$ & 0.0001 & $1,622.41$ & 0.1967 \\
\hline $\mathrm{C} \times \mathrm{P}$ & 5 & 29.13 & 0.6459 & 210.57 & 0.0002 & 83.43 & 0.0380 & 517.06 & 0.0059 \\
\hline Error B & 130 & 43.40 & & 40.98 & & 34.25 & & 150.31 & \\
\hline
\end{tabular}

${ }^{\mathrm{z}}$ Analysis of variance conducted as split plot, where $\mathrm{P}$ rate (continuous variable) is main plot and cultivars are subplots.

Table 4. Marketable yield, $\mathrm{P}$ uptake, and total plant mass of six crisphead lettuce cultivars as affected by $\mathrm{P}$ rate during three seasons in Florida.

\begin{tabular}{|c|c|c|c|c|c|c|c|c|c|c|c|c|c|c|c|c|c|c|c|}
\hline \multirow[b]{3}{*}{$\begin{array}{l}\text { Experi- } \\
\text { ment }\end{array}$} & \multirow[b]{3}{*}{ Cultivar } & \multicolumn{5}{|c|}{$\mathrm{P}$ rate $\left(\mathrm{kg} \cdot \mathrm{ha}^{-1}\right)$} & \multicolumn{6}{|c|}{ P rate $\left(\mathrm{kg} \cdot \mathrm{ha}^{-1}\right)$} & \multirow[b]{3}{*}{$\begin{array}{l}\text { Signi- } \\
\text { ficance }\end{array}$} & \multicolumn{5}{|c|}{$\mathrm{P}$ rate $\left(\mathrm{kg} \cdot \mathrm{ha} \mathrm{a}^{-1}\right)$} & \multirow[b]{3}{*}{$\begin{array}{l}\text { Signi- } \\
\text { ficance }\end{array}$} \\
\hline & & 0 & 50 & 100 & 200 & 400 & \multirow[b]{2}{*}{$\begin{array}{l}\text { Signi- } \\
\text { ficance }\end{array}$} & 0 & 50 & 100 & 200 & 400 & & 0 & 50 & 100 & 200 & 400 & \\
\hline & & \multicolumn{5}{|c|}{$\begin{array}{l}\text { Total mass } \\
\left(\mathrm{Mg} \cdot \mathrm{ha}^{-1}\right)\end{array}$} & & \multicolumn{5}{|c|}{$\begin{array}{c}\text { Marketable yield } \\
\left(\mathrm{Mg} \cdot \mathrm{ha}^{-1}\right)\end{array}$} & & \multicolumn{5}{|c|}{$\begin{array}{l}\text { P uptake } \\
\left(\mathrm{kg} \cdot \mathrm{ha}^{-1}\right)\end{array}$} & \\
\hline \multirow{7}{*}{$\begin{array}{r}\text { Winter } \\
1989\end{array}$} & & & & & & & & & & & & & & & & & & & \\
\hline & South Bay & 18.7 & 26.3 & 35.2 & 41.0 & 48.4 & $\mathrm{~L}^{* *} \mathrm{Q}^{*}$ & 0 & 0.7 & 6.4 & 14.3 & 21.9 & $\mathrm{~L}^{* *}$ & 4.5 & 7.8 & 13.2 & 16.2 & 21.0 & $\mathrm{~L}^{* *} \mathrm{Q}^{*}$ \\
\hline & Raleigh & 14.6 & 24.3 & 30.7 & 32.8 & 44.0 & $\mathrm{~L}^{* *}$ & 0 & 0.6 & 2.8 & 5.3 & 19.9 & $\mathrm{~L}^{* *}$ & 4.7 & 8.4 & 9.8 & 13.8 & 15.6 & $\mathrm{~L}^{* *} \mathrm{Q}^{*}$ \\
\hline & Salinas & 17.9 & 24.9 & 33.0 & 38.6 & 49.7 & $\mathrm{~L}^{* *}$ & 0.2 & 1.6 & 4.1 & 5.3 & 34.3 & $\mathrm{~L}^{* *}$ & 4.5 & 6.9 & 9.8 & 13.0 & 20.0 & $\mathrm{~L}^{* *}$ \\
\hline & $\begin{array}{l}\text { Ithaca } \\
\text { Florical }\end{array}$ & 22.8 & 29.8 . & 35.8 & 43.5 & 51.0 & $\mathrm{~L}^{* *} \mathrm{Q}^{*}$ & 0 & 0 & 0.9 & 6.7 & 18.8 & $\mathrm{~L}^{* *}$ & 4.5 & 6.8 & 8.1 & 12.8 & 16.8 & $\mathrm{~L}^{* * *}$ \\
\hline & 50011 & 18.7 & 30.1 & 36.2 & 48.7 & 47.1 & $\mathrm{~L}^{* *} \mathrm{Q}^{* *}$ & 2.1 & 0.8 & 5.6 & 30.6 & 27.3 & $\mathrm{~L}^{* *} \mathrm{Q}^{*}$ & 4.5 & 9.1 & 11.7 & 17.5 & 18.8 & $\mathrm{~L}^{* *} \mathrm{Q}^{* *}$ \\
\hline & 48060 & 17.1 & 26.1 & 31.3 & 30.9 & 38.8 & $\mathrm{~L}^{* *} \mathrm{Q}^{*}$ & 0 & 0.6 & 4.5 & 2.8 & 13.3 & $\mathrm{~L}^{* *}$ & 4.3 & 7.5 & 9.4 & 10.4 & 14.1 & $\mathrm{~L}^{* *} \mathrm{Q}^{*}$ \\
\hline \multirow{7}{*}{$\begin{array}{r}\text { Winter } \\
1990\end{array}$} & & & & & & & & & & & & & & & & & & & \\
\hline & South Bay & 29.5 & 34.9 & 33.5 & 37.2 & 39.3 & $\mathrm{~L}^{* *}$ & 17.9 & 20.9 & 21.8 & 24.6 & 19.0 & NS & 14.6 & 17.3 & 17.0 & 22.1 & 26.0 & $\mathrm{~L}^{* *}$ \\
\hline & Raleigh & 26.0 & 34.2 & 37.5 & 35.9 & 41.3 & $\mathrm{~L}^{* *}$ & 11.1 & 20.1 & 22.2 & 23.2 & 13.5 & $\mathrm{~L}^{*} \mathrm{O}^{*}$ & 13.4 & 15.7 & 20.3 & 20.6 & 28.1 & $\mathrm{~L}^{* *}$ \\
\hline & Salinas & 23.4 & 26.8 & 25.1 & 29.9 & 35.9 & $\mathrm{~L}^{* *}$ & 0 & 0.9 & 0 & 1.8 & 4.7 & NS & 10.2 & 12.6 & 12.4 & 16.2 & 23.1 & $\mathrm{~L}^{* *}$ \\
\hline & Ithaca & 16.5 & 20.5 & 24.4 & 30.7 & 32.5 & $\mathrm{~L}^{* *} \mathrm{Q}^{*}$ & 0 & 1.0 & 5.8 & 9.2 & 4.2 & $\mathrm{~L}^{*} \mathrm{Q}^{*}$ & 6.1 & 8.0 & 12.2 & 14.4 & 20.8 & $\mathrm{~L}^{* *} \mathrm{Q}^{*}$ \\
\hline & 50011 & 29.9 & 34.2 & 40.4 & 41.8 & 47.6 & $L^{* *}$ & 16.6 & 21.7 & 26.6 & 28.8 & 30.9 & $L^{* *}$ & 12.5 & 15.8 & 21.3 & 24.5 & 30.2 & $L^{* *}$ \\
\hline & Florical & 354 & 10 & 304 & 457 & $15 ?$ & & 1 & $21 ?$ & 212 & 105 & & & & & & & & * \\
\hline \multirow{8}{*}{$\begin{array}{l}\text { Fall } \\
\qquad 1990\end{array}$} & 48000 & 35.4 & 40.1 & 39.4 & 43.1 & 43.2 & $L^{* *}$ & 18.0 & 21.2 & 21.3 & 18.5 & 19.5 & NS & 14.6 & 18.6 & 25.5 & 17.9 & 28.0 & $\mathrm{~L}^{* *} \mathrm{Q}^{*}$ \\
\hline & South Bay & 20.7 & 28.5 & 31.6 & 32.6 & 38.7 & $L^{* *} Q^{* *}$ & 0.8 & 6.1 & 14.1 & 13.1 & 22.5 & $\mathrm{~L}^{* *} \mathrm{Q}^{*}$ & 5.8 & 8.3 & 10.6 & 11.6 & 13.1 & $\mathrm{~L}^{* *} \mathrm{Q}^{* *}$ \\
\hline & Ralcigh & 22.4 & 32.4 & 38.0 & 44.7 & 44.4 & $L^{* *} Q^{* *}$ & 0 & 15.5 & 22.9 & 33.8 & 37.2 & $\mathrm{~L}^{* *} \mathrm{Q}^{* *}$ & 6.4 & 8.4 & 12.7 & 17.7 & 16.1 & $\mathrm{~L}^{* *} \mathrm{Q}^{* *}$ \\
\hline & Salinas & 22.5 & 34.5 & 33.9 & 45.5 & 44.3 & $\mathrm{~L}^{* *} \mathrm{Q}^{*}$ & 0 & 4.4 & 11.5 & 22.2 & 35.1 & $\mathrm{~L}^{*}$ & 7.5 & 9.8 & 11.8 & 15.0 & 19.8 & $L^{* *}$ \\
\hline & Ithaca & 20.5 & 29.5 & 31.7 & 32.6 & 37.4 & $\mathrm{~L}^{* *}$ & 0 & 0.6 & 4.0 & 13.1 & 14.7 & $\mathrm{~L}^{* *}$ & 5.3 & 8.6 & 10.4 & 11.6 & 13.0 & $\mathrm{~L}^{* *} \mathrm{Q}^{*}$ \\
\hline & $\begin{array}{c}\text { Florical } \\
50011\end{array}$ & 22.4 & 36.3 & 369 & 45.5 & 457 & $\mathrm{~L}^{* *} \mathrm{O} * *$ & 0 & 18 & 18.8 & 222 & 313 & ** & 57 & 111 & 118 & 151 & 107 & I** \\
\hline & Florical & & & & & & & & & & & & & & & 11.8 & 15.1 & 19.2 & L \\
\hline & 48060 & 14.3 & 21.4 & 28.3 & 29.8 & 31.4 & $\mathrm{~L}^{* *} \mathrm{Q}^{* *}$ & 0 & 0 & 0 & 0 & 0 & $\ldots$ & 3.8 & 5.4 & 7.7 & 9.3 & 14.3 & $L^{* *}$ \\
\hline
\end{tabular}

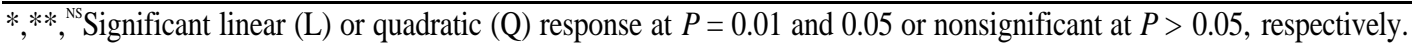

negligible -marketable yield. The significant interaction this year was largely associated with the poor growth of these two cultivars under the conditions encountered. It should be noted that 'Salinas' is known to tolerate frost when grown in the western United States, where temperature changes are more gradual. However, under Florida conditions, where a freeze may immediately follow several days of high temperature $(>27 \mathrm{C})$, 'Salinas' apparently was not tolerant.

In Spring 1990, lettuce yields were limited by high temperatures. The significant $\mathrm{P}$ rate $\times$ cultivar interaction this season was largely associated with fhe inability of 'Florical 48060' to produce marketable yield during the warm weather.

The observation that the range of lettuce cultivars produced in Florida shows a strong interaction with environmental conditions is well established (Burdine, 1971; Guzman, 1981). In southern Florida, lettuce is planted every day, weather permitting, from 1.5 Sept. to 15 Mar. and harvested every day from
15 Nov. to 15 May. Stress conditions such as those encountered in these experiments are not uncommon. The ability of individual cultivars to produce marketable lettuce heads under the various stress conditions encountered during Winter 1989, Winter 1990, and Spring 1990 undoubtedly influenced the ability of these cultivars to respond to $\mathrm{P}$ fertilizer. However, with the exception of seasonal trends in mean temperature, weather conditions in southern Florida are impossible to predict, and there is little basis for adjusting $\mathrm{P}$ soil-test fertilizer recommendations for season. This fact further compounds the complicated season $\times$ cultivar $\times \mathrm{P}$ rate interactions. Further, to the best of their ability, growers plant cultivars best adapted to individual seasons. 'Salinas' is not well adapted to Florida conditions and is not grown. 'Florical 50011' and 'Florical 48060' are generally adapted to cool weather and are only planted from December to January. Hence, soil-test $\mathrm{P}$ fertilizer recommendations that are based on long-term probability and risk considerations must 

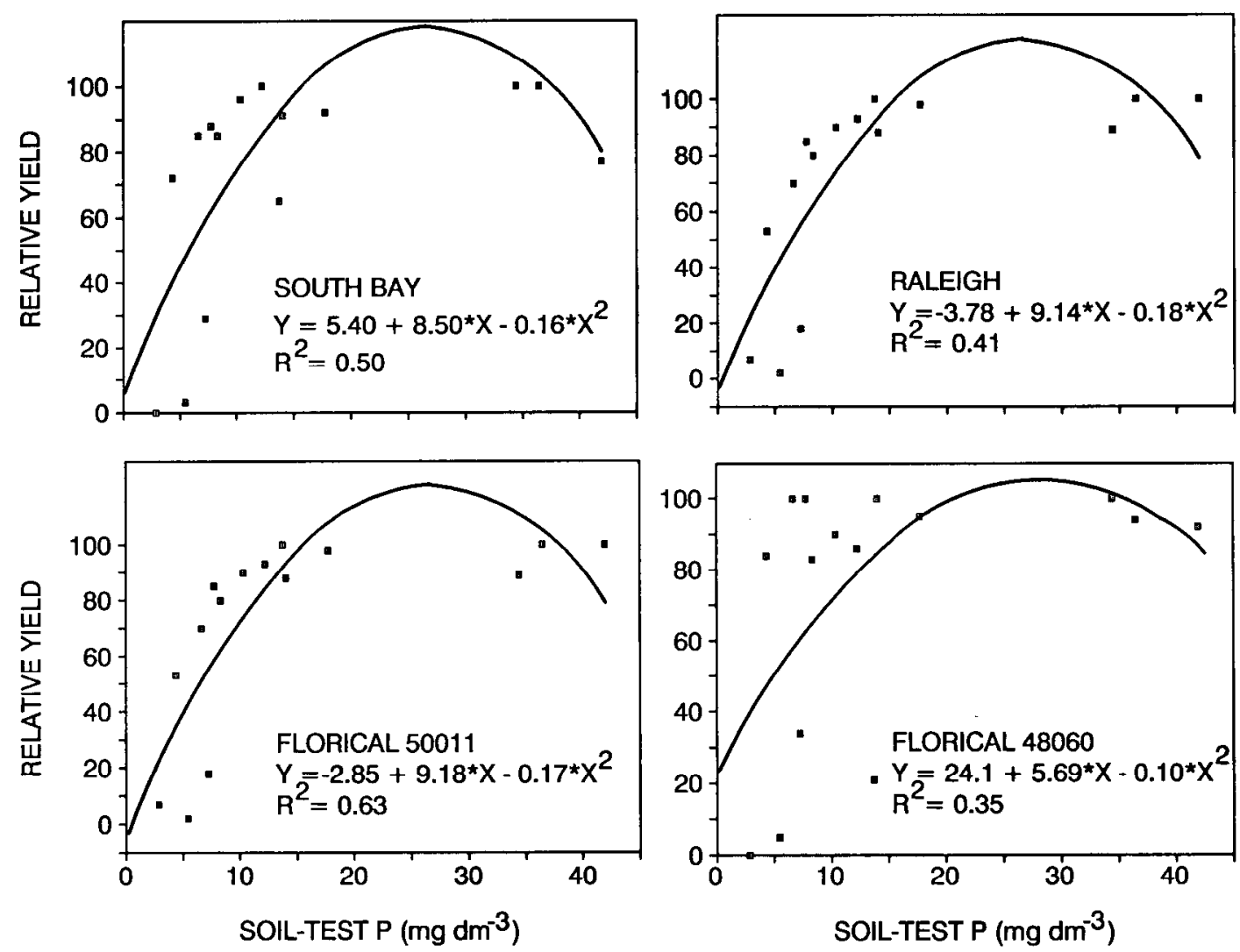

Fig. 1. Relative yield of four lettuce cultivars as affected by soil-test P level.

be made for production of economically optimal yields under nearly optimal conditions (Alvarez and Sanchez, 1991).

Phosphorus fertilizer recommendations for lettuce produced on Florida Histosols are based on a water-soluble $\mathrm{P}$ soil test (Sanchez, 1990). Currently, $\mathrm{P}$ fertilizer recommendations are made for lettuce produced on all soils with $\mathrm{P}$ test levels $<22$ $\mathrm{mg} \cdot \mathrm{dm}^{-3}$. The amount of $\mathrm{P}$ applied depends on the degree to which the $\mathrm{P}$ soil test is below the critical level (Sanchez and Burdine, 1988). The relationship between relative yield and soiltest $\mathrm{P}$ obtained in these experiments indicates that the critical soil-test $\mathrm{P}$ levels for all cultivars produced in Florida (Fig. 1) are within error of that currently used to make $\mathrm{P}$ fertilizer recommendations for lettuce produced on Histosols in Florida.

In conclusion, there were no significant $\mathrm{P}$ rate $\times$ cultivar interactions for total mass produced and $\mathrm{P}$ uptake. There was no significant $\mathrm{P}$ rate $\mathrm{x}$ cultivar interaction for marketable yield during Fall 1988 when growing conditions were near ideal. Calculated critical soil-test $\mathrm{P}$ values for both eastern and western lettuce types produced in Florida were all within the error of the critical concentration currently associated with $\mathrm{P}$ fertilizer recommendations for lettuce produced in Florida. Further, growers generally plant cultivars best suited to individual seasons. Therefore, we conclude that no immediate change in $\mathrm{P}$ fertilizer recommendations is required for the new western-type lettuce cultivars produced in Florida.

\section{Literature Cited}

Alt, D. 1987. Influence of $\mathrm{P}$ and $\mathrm{K}$ fertilization on the yield of different vegetable species. J. Plant Nutr. 10:1429-1435.

Alvarez, J. and C.A. Sanchez. 1991. Phosphorus application constraints limit profitability of sweet corn and lettuce production. HortScience 26:307-309.
Burdinc, H.W. 1971. Lettuce cultivar response to the south Florida environment. Proc. Fla. State Hort Soc. 85:135-140.

Greenwood, D.J., T.J. Cleaver, M.K. Turner, J. Hunt, K.B. Niedorf, and S.M. Loquens. 1980. Comparisons of the effects of phosphate fertilizer on yield, phosphate content, and quality of 22 different vegetables and agricultural crops. J. Agr. Sci. (Camb.) 95:457-469.

Guzman, V.L. 1981. Yield and quality response of crisphead lettuce to seeding dates and farms in south Florida organic soils. Proc. Fla. State Hort. Soc. 94:182-185.

Guzman, V.L. and D.D. Gull. 1984. 'Southbay and Raleigh' Two crisphead lettuce cultivars resistant to corky root rot for organic soils. Univ. Florida Agr. Expt. Sta. Circ. S-310.

Guzman, V.L., T.A. Zitter, and D.D. Gull. 1990. Florical 48060 and Florical 50011. Univ. Florida Agr. Expt. Sta. Circ. S-366.

Sanchez, C.A. 1990. Soil testing and fertilizer recommendations for crop production on organic soils in Florida. Univ. Florida Agr. Bul. 876.

Sanchez, C.A. and H.W. Burdine. 1988. Relationship between lettuce yields and soil-test P and K levels. Soil Crop Sci. Soc. Fla. Proc. 47:52-56.

Sanchez, CA., H.W. Burdine, V.L. Guzman, and C.B. Hall. 1988. Yield and leaf nutrient composition of crisphead lettuce as affected by $\mathrm{N}, \mathrm{P}$, and $\mathrm{K}$ on Histosols. Proc. Fla. State Hort. Soc. 101:346-350.

Sanchez, C.A., S. Swanson, and P.S. Porter. 1990. Relative efficiency of broadcast and banded P for lettuce. J. Amer. Soc. Hort. Sci. 115:581584.

SAS Institute. 1982. SAS user's guide: Statistics. 1982 ed. SAS Institute, Gary N.C.

Snyder, G.H., H.W. Burdine, J.R. Crockett, G.J. Gascho, D.S. Harrison, G. Kidder, J.W. Milshoe, D.L. Myhre, F.M. Pate, and S.F. Shih. 1978. Water table management for organic soil conservation and crop production in the Florida Evcrglades. Univ. Florida Bul. 801.

Thompson, R.C. and E.J. Ryder. 1961. Descriptions and pedigrees of nine varieties of Icttuce. U.S. Dept. Agr. Tech. Bul. 1244.

U.S. Dept. of Agriculture. 1973. USDA standards for grades of lettuce. U.S. Dept. Agr. Mktg. Serv., Washington, D.C.

Wolf, B. 1982. A comprehensive system of leaf analysis and its USC for diagnosing crop nutrient status. Commun. Soil Sci. Plant Anal. 13:10351059 . 